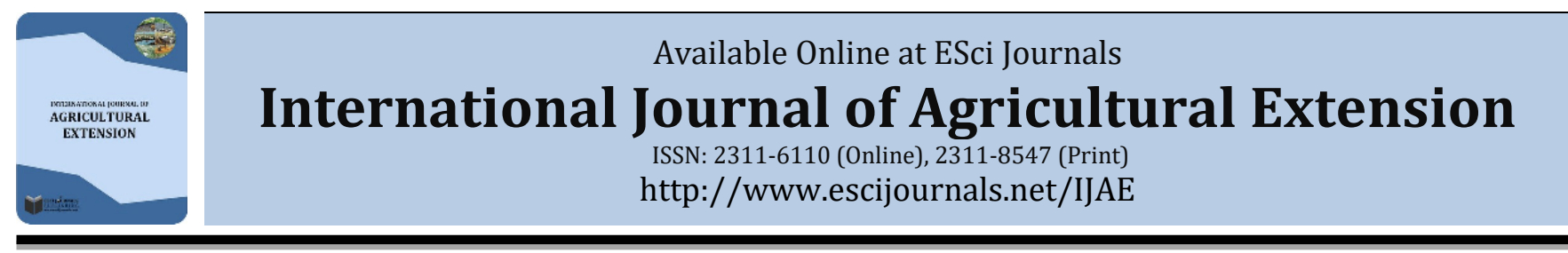

\title{
COMMUNICATION MODALITIES USED IN THE DELIVERY OF EXTENSION PROGRAMS TO SMALL SCALE LIVESTOCK RAISERS IN SAN JOSE, OCCIDENTAL MINDORO, PHILIPPINES
}

\author{
Mary Y. A. Declaro-Ruedas*, Leoniel S. Bais \\ College of Agriculture, Occidental Mindoro State College San Jose, Occidental Mindoro, Philippines.
}

\begin{abstract}
A B S T R A C T
This study was conducted to determine the communication modalities used in extension program offered to livestock raisers in San Jose, Occidental Mindoro, Philippines. This study utilized the descriptive research method. The data were collected through questionnaire. All data was organized, classified, and interpreted using descriptive statistics. Results show that the small scale livestock raisers in San Jose, Occidental Mindoro were mostly male, middle aged, with low level of education and had been raising not more than five heads of livestock. Majority have a long experience of livestock production. Most of them rated the quality of support services provided to them as "good". One-on-one method is the most common communication modality used by the extension workers, however the preferred modality is the conduct of seminar/conferences. The problems encountered on the adoption of technologies were the financial constraint, lack of institutional support, and the mismatch of the message and the communication media used by the extension worker.
\end{abstract}

Keywords: Communication approaches, extension, animal extension providers.

\section{INTRODUCTION}

The livestock sector plays a crucial role in the economies of many developing countries as an important source of protein-rich products. It is a vital generator of employment. For many farmers in the developing world, livestock also provides a means of storing wealth, a cushion for food shortages, and a source of fertilizer and or fuel, a means of transportation, and as source of traction in agricultural production (World Bank, 2003).

Livestock services can be grouped into two major functional categories: health and production services. Health services include curative and preventive services and the provision of pharmaceuticals. Curative services include the provision of clinical care, while preventive services consist of vaccination, vector control, eradication programs, and disease control measures such as quarantines, the slaughter of diseased animals and movement restrictions. On the other hand, production services include research and extension

* Corresponding Author:

Email: tsinelas_yole@yahoo.com

(C) 2019 ESci Journals Publishing. All rights reserved. relating to improved livestock husbandry and the provision of input supplies such as seeds, feeds and artificial insemination (World Bank (2003),

Consequently, the major players that shape the livestock services sector are veterinarians and veterinary paraprofessionals, herders, consumers, government, inter-governmental, non-governmental donors in developed countries.

Most of the livestock backyard raisers engage in production as a "sideline" activity that serves as an emergency source of funds in case of financial problem. Hence, they are very receptive to new and/or recommended production technologies. Also, this results in the selling and slaughter of good quality animals (Eusebio \& Chantalakhana, 2002).

In developing countries where agriculture is the principle means of livelihood for about $90 \%$ of the population, strengthening the ability of agriculture to compete domestically and in export markets is an important premise for an economically competitive agricultural sector (Jazairy, 1992). Further, the quality, capability and performance of farmers in agriculture are 
fundamental indicators of the level of the agricultural sectors efficiency, productivity, development and sustainability (Maalouf et al., 1991).

Rivera et al. (1991) reported that most farmers in the developing world have a low level of formal education and extremely few have the opportunity to study agriculture in the formal school system. As observed in developed countries, it can be inferred that education is important to develop the agricultural and livestock sectors. In reality, extension services, and research are important in adopting new technologies for the advancement of farmers with low knowledge levels.

According to FAO (2005), agricultural extension is available to only 1 out of every 5 farmers in the developing regions of the world. Studies also show that in Asia, 3 out of every 4 farmers have no contacts with public extension services (Maalouf et al., 1991).

Agricultural extension work is a significant social innovation, an important force in agricultural change, which has been created and recreated, adapted and developed over the centuries. Today, the organizations and personnel engaged in agricultural extension encompass a diverse range of socially sanctioned and legitimate activities which seek to enlarge and improve the abilities of farm people to adopt more appropriate and often new practices and to adjust to changing conditions and societal needs (Jones \& Garforth, 1997).

The services provided by extension have significant public-good attributes. It is estimated that there are at least 800,000 official extension workers worldwide, and some $80 \%$ of the world's extension services are publicly funded and delivered by civil servants (Feder et al., 2001). Universities, autonomous public organizations, and NGOs deliver about $12 \%$ of extension services, and the private sector delivers another $5 \%$ (The World Bank, 2003).

Agricultural extension responsibilities include the transferring of knowledge from researchers to farmers, advising farmers in their decision making and educating farmers on how to make better decisions, enabling farmers to clarify their own goals and possibilities, and stimulating desirable agricultural developments (Van den Ban and Hawkins, 1996). Extension is a function pursuing many different purposes (Rivera et al., 2001). In addition, the effectiveness of extension programs is the key to the development of the agricultural and livestock sectors.

Shifting trends in agriculture are affecting the traditional roles of agricultural extension. Numerous authors like Qamar (2000), Rivera et al. (2001), and Swanson et al. (2003) suggest that agricultural extension organizations in both developed and developing countries are undergoing considerable re-examination and change due to the "new agriculture."

Furthermore, the challenge of addressing these needs are complicated by both the limited access of farmers to relevant agricultural information and the public sector's apparent dearth of financial resources for agricultural extension. In this regard if extension is to be relevant and responsive in the 21st century, it needs to service farm families in an increasingly complex, interdependent, rapidly changing, resource stressed world and it must be affordable (Antholt, 1991).

However, studies that particularly focus on the communication modalities used in extension programs offered to the small scale livestock raisers in San Jose, Occidental Mindoro are lacking. Finding out the communication modalities used in extension is important as there could be a predictor for an effective and efficient extension program. For this reason, it is necessary to ascertain the perception of the small scale livestock raisers about the extension services provided to them in the last three years; determine the communication modalities used and identify the problems encountered in the delivery of extension service.

\section{METHODOLOGY}

This study was conducted in the municipality of San Jose, Occidental Mindoro. It is one of the eleven municipalities of the province. It is located at the southern part of the province with a total land area of 55, 192.94 hectares comprising of 38 barangays. The municipality is basically an agricultural community, which focuses on crops and livestock (MPDO San Jose, 2006).

Respondents consisted of small scale livestock raisers in San Jose, Occidental Mindoro, Philippines. A total of 87 respondents were randomly selected from the list of backyard raisers in the Municipal Agriculture Office of San Jose, Occidental Mindoro, Philippines. It included the herdsman, caretaker, employee or tenant of any firm or entity engaged in the raising of large ruminants owning less than 20 heads, which is considered as backyard raisers according to Bureaus of Animal Science classification.

This study utilized the descriptive research method. The data were collected through questionnaire. All data was 
organized, classified, and interpreted statistically. The descriptive statistics that was used are the mean, standard deviation, frequency distribution and percentage were employed.

\section{RESULTS AND DISCUSSIONS}

\section{Small scale Livestock raisers in San Jose, Occidental}

Mindoro: According to Ours (2010), labour productivity declines in between 40-50 years old. Since older farmers are more conservative and reluctant to accept risk and they work fewer hours and fewer nonfarm employments. Based on the survey conducted as summarized on table 1 below, the respondents had a mean age of 48.33 years and are within the middle age. Furthermore, in terms of the distribution of sex, majority of the large ruminant raisers are male (75.86\%) while $24.13 \%$ are female. In terms of number of large ruminant raised had a mean of 3.72 this implies that majority respondents raise not more than 5 heads either cattle or carabao. Further, in terms of the number of years engaged in production, majority of the large ruminant raisers have an experience of not more than 10 years (49.43\%) while only $3.45 \%$ has been engaged in production for more than 31 years.

Lastly, in terms of educational attainment, most $(41.38 \%)$ of the respondents attained high school level. This corroborates with the study of Rivera et al. (2001) that most farmers in the developing world have a low level of formal education and extremely few have the opportunity to study agriculture in the formal school system. As observed in developed countries, it can be inferred that education is important to develop the agricultural and livestock sectors. In reality, extension services are continually important even to educated farmers, and research and learning that accompanies adoption of new technologies is especially important for the advancement of farmers with low knowledge levels.

Table 1. Distribution of respondents according to demographic characteristics.

\begin{tabular}{|c|c|c|c|c|}
\hline Demographic Characteristic & Category & Frequency & Percentage & Mean \\
\hline Age & & & & $48.33+8.13$ \\
\hline \multirow[t]{2}{*}{ Sex } & Male & 66 & 75.86 & \\
\hline & Female & 21 & 24.13 & \\
\hline Number of large ruminant raised & & & & $3.72+3.69$ \\
\hline \multirow{4}{*}{$\begin{array}{l}\text { Number of years in large ruminant } \\
\text { production }\end{array}$} & Less than 10 years & 43 & 49.43 & \\
\hline & $11-20$ years & 31 & 35.63 & \\
\hline & 21-30 years & 10 & 11.49 & \\
\hline & More than 31 years & 3 & 3.45 & \\
\hline \multirow[t]{7}{*}{ Education Attainment } & No formal Education & 1 & 1.15 & \\
\hline & Elementary Undergraduate & 21 & 24.14 & \\
\hline & Elementary Graduate & 6 & 6.90 & \\
\hline & High School Undergraduate & 36 & 41.38 & \\
\hline & High School Graduate & 8 & 9.20 & \\
\hline & College Undergraduate & 11 & 12.64 & \\
\hline & College Graduate & 4 & 4.60 & \\
\hline
\end{tabular}

Perception on the quality of extension services: Extension service providers should be saddled with the responsibility of ensuring that farmers are continually satisfied with services being delivered (Agholor et al., 2013). Hackman and Wageman (1995) stated that "uncontrolled variance in process or outcomes is the primary cause of quality problems." Quality is the direct result of work processes within the organization and, in the area of extension, it relates to aspect of programming and delivery of educational interventions.
Table 2 presents the perception of the large ruminant raisers on the quality of extension services offered to them. Majority (73.56\%) of the respondent experienced "good" quality of support services delivered while 3.45\% said that they have no experience with any extension services this is supported by Rivera (2003) extension resources are available to only 3 out of every 5 farmers in the developing regions of the world. Moreover, $94.25 \%$ of the large ruminant raisers interviewed said that the technical assistance programs for the 
production of large ruminants are available in the community.

Table 2. Perception of large ruminant raisers on the quality of support services.

\begin{tabular}{lcc}
\hline Ratings & Frequency & Percentage \\
\hline Excellent & 4 & 4.60 \\
Good & 64 & 73.56 \\
Bad & 16 & 18.39 \\
No experience with extension & 3 & 3.45 \\
\hline
\end{tabular}

Communication modalities used by the extension workers: Delivery methods can be classified according to the nature of the contact, the form of communication modalities or function (Seevers et al., 1997). Furthermore, delivery methods can be classified according to the stage at which the method can be used in the learning process (Richardson, 1996).

Based on Richardson (1996) classification, delivery methods are classified into four categories: experiential, reinforcement, integrative, and other which includes other medium of communication such as, print media, television, and radio.

Table 3a below presents the educational methods in the delivery of extension services to large ruminant raisers by extension workers. One-on-one method is the most (56.32\%) common delivery method and classified as reinforcement Baconguis (2007) concluded that one-onone method remain dominant. Thus, with the limited number of technical persons, technical advises and government programs reach only a select few. While the visitation to other farm (3.45\%) is applied the least by the extension workers as a means of providing service to large ruminant raisers.

Table 3a. Communication modalities used by the extension workers.

\begin{tabular}{llcc}
\hline Methods* & Category & Frequency & Percentage \\
\hline Process demonstration & Experiential & 41 & 47.13 \\
Result demonstration & Experiential & 4 & 4.60 \\
Seminars/conferences & Reinforcement & 38 & 43.68 \\
Field days & Experiential & 7 & 8.05 \\
One-on-one & Reinforcement & 49 & 56.32 \\
Visit other farm & Experiential & 3 & 3.45 \\
\hline
\end{tabular}

*multiple response.

In the case of educational delivery methods preferred by large ruminant raisers, seminars/conferences (60.92\%) is the most preferred delivery methods. The same with the result on the preference of extension workers on different educational delivery methods, large ruminant raisers least prefer the visitation to other farms.

Table 3b. Preferred communication modalities by the small scale livestock raisers.

\begin{tabular}{llcc}
\hline Methods* & Category & Frequency & Percentage \\
\hline Process demonstration & Experiential & 8 & 9.20 \\
Result demonstration & Experiential & 15 & 17.24 \\
Seminars/conferences & Reinforcement & 53 & 60.92 \\
Field days & Experiential & 5 & 5.74 \\
One-on-one & Reinforcement & 50 & 57.47 \\
Visit other farm & Experiential & 5 & 5.75 \\
\hline
\end{tabular}

*multiple response.

Small holders rely mainly on information from friends, relatives and the local government units whose reach depend primarily on funds available. In contrast, Table $3 \mathrm{c}$ below shows that $74.71 \%$ of the large ruminant raisers rely on other farmers for information and advice for their production while $3.45 \%$ of large ruminant raisers rely solely on their own experience. In addition it indicates that there is no permanent extension services provided to them. Rivera et al. (2001) stated that extension worldwide had been criticized for not doing 
enough, not doing it well, and for not being relevant. Critics emphasized the insufficient impact in effectiveness, in efficiency, and the lack of programs that fostered equity.

Extension benefits of large ruminants' raisers: Extension services being delivered by the extension workers to the community are expected to provide benefits to its target clients. As for the large ruminants' raisers in the selected barangays of San Jose, Occidental Mindoro, the most common benefit that they get from extension programs given by the government and academic institutions is the access to new information in regular basis according to 42 raisers comprising $48.28 \%$ of the respondents interviewed.

Table 3c. Sources of information used by the large ruminant raisers.

\begin{tabular}{lcc}
\hline Sources of information* & Frequency & Percentage \\
\hline Veterinarian & 39 & 44.83 \\
Salesmen & 1 & 1.15 \\
Other farmer & 65 & 74.71 \\
Agricultural technicians & 26 & 29.89 \\
Farmers association agent & 5 & 5.75 \\
Rely on own experience & 3 & 3.45 \\
\hline
\end{tabular}

*multiple response.

Table 4. Benefits received from extension program of large ruminants' raisers.

\begin{tabular}{lcc}
\hline Benefits* & Frequency & Percentage \\
\hline Avail discount & 19 & 21.84 \\
Representation in the sector & 5 & 5.75 \\
Access to new information on regular basis & 42 & 48.28 \\
Participations in conferences and seminar & 3 & 3.45 \\
Opportunities to share experience with others & 2 & 2.30 \\
Training for farm workers & 20 & 22.99 \\
No benefits & 19 & 21.84 \\
\hline
\end{tabular}

*multiple response.

Problems encountered by large ruminant raisers on technology adoption: According to the respondents, the most common problem that is encounter on the adoption of technologies is the financial constraint (56.32\%). This is supported by the World Bank (2003), suggesting that cost effectiveness and financial sustainability could be improved if farmer-trainers were to become the main trainers, perhaps with significant community funding, and if informal farmer-to-farmer communications were to facilitate knowledge diffusion. Another problem encountered by the large ruminant raisers is the lack of technical capability (48.28\%) to adopt the technology specifically the artificial insemination (AI) which was worsened by the lack of financial capability which is the most common problem encountered by the respondents.

Furthermore, the lack of institutional support (16.09\%) and inappropriate types of communication used (16.09\%) are some problems rarely encountered by the large ruminant raisers during the adoption of technologies extended to them by the extension workers.

Table 5. Problem encountered in the adoption of technologies.

\begin{tabular}{lccc}
\hline Problems* & Frequency & Percentage & Rank \\
\hline Financial constraint & 49 & 56.32 & 1 \\
Lack of technical capability to adopt the technology & 42 & 48.28 & 2 \\
Lack of institutional support & 14 & 16.09 & 3.5 \\
Inappropriate types of communication used & 14 & 16.09 & 3.5 \\
\hline
\end{tabular}

*multiple response. 


\section{CONCLUSION AND RECOMMENDATIONS}

The small-scale livestock raisers in San Jose, Occidental Mindoro, Philippines experienced "good" quality of support services received extension service in their community. Methods commonly used by extension officers to deliver extension programs is the one-on-one method however the preferred modality is the conduct of seminar/conferences. Thus, content and delivery methods should be carefully selected and varied so that the desired results are achieved.

Further, the problems encountered on the adoption of technologies were the financial constraint, the lack of institutional support and the inappropriate types of communication modalities used by the extension workers. Following these findings, concerted effort is required to improve extension services in the livestock sector by integrating participatory and experiential approaches.

Lastly, for effective and efficient extension delivery livestock raisers must be encouraged to form associations as this will assist in information dissemination.

\section{REFERENCES}

Agholor, I., Monde, N., Obi, A. \& Sunday,O. (2013). Quality of Extension Services: A Case Study of Farmers in Amathole. Journal of Agricultural Science, 5, 2.

Antholt, C.H. (1991). Agricultural extension in the 21st Century: Lessons from South Asia. New York, NY: Elsevier Science publishing Company.

Bureau of Agricultural Statistics. (2014). Cattle Industry Performance

Report. http://www.bas.gov.ph/download_action.php?filed own=

Blackburn, D. J. (ed) (January, 1994). Extension Handbook: Processes and Practices. Bureau of Animal Industry. (2000). Industry Paper on the Phil. Meat Industry.Mimeographed Copy, 30 p. Quezon City, Phil.

Castillo, A. C. (2004). Backyard beef production in the Philippines. Retrieved from http://opendocs.ids.ac.uk/opendocs/bitstream/ha ndle/713

Caviglia-Harris, J.L. (2001) Sustainable agricultural practices in Rondônia, Brazil: Do local farmer organizations impact adoption rates? Retrieved http://weber.ucsd.edu

Eusebio, A.N. \& Chantalakhana C. (2002). Backyard DairyBeef Farming and Feed grains Substitutes in the Philippine and Thailand. ASPAC-FFTC Extension Bull.No. 114.

Feder, G., Willett, A., \&Zijp. (2001). Agricultural extension: Generic challenges and the ingredients for solutions. In S. Wolf and D. Zilberman (Eds.), Knowledge generation and technical change: Institutional innovation in agriculture

Hackman., J. K., \& Wageman, R. (1995). Total Quality Management: Empirical and practical Issues. Administrative Sciences. Quality, 40(2), 309-342.

Jazairy, Y. (1992). The State of World Rural Poverty: An inquiry into its causes and consequences. New York: International Fund for Agricultural Development.

Jones, G.E., \& Garforth, C. (1997). The history, development, and future of agricultural extension. In B.E. Swanson, R.P. Bentz, \& A.J. Sofranko (Eds.), Improving Agricultural Extension: A reference manual (pp.3-12). Rome: FAO.

Maalouf, W.D., Contado, Adhikarya, R., \& Contado, T. (1991). Extension coverage and resource problems: The need for public-private cooperation. In W.M. Rivera \& D.F. Gustafson (Eds.), Agricultural extension: Worldwide institutional evolution and forces for change (pp. 59-70). New York, NY: Elsevier Science Publishing Company.

PCARRD. (2008). Bautista, O. Livestock and Crops Database, in Region IV-B.

Qamar, M.K. (2000). Agricultural extension at the turn of the millennium: trends and challenges; Human resources in agricultural and rural development. Rome: FAO.

Richardson J. (1997). Extension education: process and practice. Targeting audiences in developing program delivery systems. Retrieved from http://www.ces.ncsu.edu/resources/education/sd. 